\title{
Philosophische Monatshefte.
}

Unter Mitwirkung

von

\author{
Prof. Dr. Fr. A scherson,
} Bibliothekar an der Uiniversititsbibliothek zu Berlin,

sowie mehrerer mamlnarten Fachgelehrten

redigirt und heransgegeben

von

Prof. Dr. Paul Natorp.

XXX. B and.

B er lin.

Verlag von Georg Reimer. 1894. 
